\title{
WHY LOCAL CONTEXT MATTERS: PROPERTY RIGHTS AND DEBT TRADING IN COLONIAL SOUTH AFRICA ${ }^{1}$
}

\author{
C. Swanepoel*a and J. Fourie ${ }^{b}$
}

\begin{abstract}
Eor economic transactions, including debt transactions, to occur in a - market system, property rights are essential. The literature has focussed on finding empirical proof of the effect of property right regimes, noting differences between de jure and de facto property rights. We use a novel combination of data on wealth and demographics to investigate the effects of property right regimes on economic outcomes at the individual level. At the Cape, de jure property rights between freehold and loan farms differed. Historians, however, suggest that de facto property rights between these two property types were the same. We exploit the random variation of the birth order, specifically being the eldest son, to estimate whether the type of farm and therefore the type of property rights, mattered for economic activity, in our case, debt transactions. Our results suggest that historians were correct: loan farms were as secure in their de facto property rights, despite differences in de jure property rights. Our results confirm that the local context in which property right regimes are embedded is at least as important as the property right regime itself.
\end{abstract}

\section{Introduction}

In order for any transaction, including debt transactions, to occur, an economic system, according to Douglas North (1989), needs 'well-specified and well-enforced property rights'. Ronald Coase (1960), too, concluded that without the delimitation

*a Department of Economics, University of the Western Cape. Email: cswanepoel@uwc.ac.za

${ }^{\mathrm{b}}$ LEAP, Department of Economics, Stellenbosch University.

${ }^{1}$ The authors would like to thank Jeanne Cilliers, Claude Diebolt, Kara Dimitruk, Joost Jonker, Sumner La Croix, Richard Hornbeck, Dieter von Fintel and seminar participants at the universities of Arizona, Stellenbosch and Utrecht for comments on an earlier version of this paper. We also thank Economic Research Southern Africa and the National Research Foundation for financial support. 
of initial rights no market transactions can take place. Such property right systems evolve, suggested Harold Demsetz (1967), from the 'laws, customs and mores of a society'. These authors formed the beginning of a study into property rights as an economic institution and their importance for economic development.

More recent studies have attempted to find empirical proof to explain the emergence and persistence of property rights systems, and their long-run impact on economic development. Two studies of the developing world stand out. Acemoglu, Johnson, \& Robinson (2001) use settler mortality as an instrument for the initial property rights systems installed by colonial powers and show that this initial system mattered for long-term development. Sokoloff \& Engermann (2000) compare different New World economies and found that regions where land was acquired with relative ease, are more affluent today. A key to the Sokoloff \& Engermann hypothesis is the relative land abundance and the unequal distribution of factor endowments.

Because of the diversity of property right systems, Africa has attracted much attention. Fenske (2012) study land abundance in nineteenth-century Nigeria and finds that land abundance caused weak property rights in land, which meant that slaves were used as collateral in market transactions rather than land. Austin (2005: 344 ), in an extensive study on the Asante in Ghana, links a change in property rights to the adoption of cocoa farming. He proposes that it was the value of the planted cocoa trees which gave the land its value and as this form of farming expanded, the land became valuable, scarcer and this ensured better-protected rights. Hopkins (1973: 38) summarizes this process as follows: ' $\ldots$ it was the product of scarce factor, labour, which was closely defined, whereas rights over land, which was in general an abundant resource, were less specific.' Goldstein \& Udry (2008) show how individuals who are uncertain of their land rights in Ghana tend to invest less, and that this lowers their productivity. Goldstein (2015), in a study on gender in Benin, found that more secure property rights increased investment in the long run for cash crops and such rights could also lead to a decrease in the gender gap in land fallowing. In Uganda from 1965 to 1995 , two different property systems, customary tenure system and 'mailo' tenure system, had different effects on agricultural outcomes (Place \& Otsuka, 2000).

Land abundance is however not the only influence on long-term persistence of land property rights. In India, different land tenure systems were observed under British rule with different long-term outcomes. Banerjee \& Iyer (2005) show that the historical districts where large landlords (equated with relatively weak property rights) were in control, less investment and productivity is observed postindependence. Dell (2010) showed that large landowners in Peru had well-defined and secure property rights. However, the large landowners, different from India, had 
the ability to protect their workforce from forced labour and in the long run, more public service provision is observed in these regions. These case studies show how the social environment of laws and norms in which the property right system evolve could result in opposite development trajectories.

This paper presents the eighteenth-century Cape Colony as another example. The Cape was land abundant; labour, often imported as slaves from the East Indies, were expensive relative to the land acquired (through conquest or disease) from the indigenous Khoisan. But two property right systems nevertheless existed: a freehold and loan farm system. Freehold farms were outright ownership of property and land. Loan farms were leaseholds were individuals did not have legal right to own the farms they cultivated. The property remained under the ownership of the Dutch East India Company (hereafter, the Company). Our aim is to show that the beliefs about property rights rather than the legally defined rights are what mattered for economic outcomes at the Cape. In this paper, we assume de jure rights are how the ownership is defined by law, while de facto rights are how these laws are observed and implemented by society.

The evolution of laws governing land ownership in the United States has been the focus of economic historians too. De Soto (2001) show how property rights laws changed over time in the US and concluded that the property law was successful once it took the social norms of settlers on the frontier into account. Focused on the effect of one particular law, the Homestead Act of 1834, Lamoreaux (2011) showed the allocation of land by the government will be fruitful as long as individuals still believe their underlying rights to the property are secure.

The legal right to use land (or have ownership of it) is, however, not the only aspect which mattered for property rights and economic development. Hornbeck (2010) demonstrated that it is equally important to have the ability to protect land, rather than only the legal right to own it. This ability to protect one's land is especially important for frontier settlements due to the continual expansion and movement of boundaries, with new land available for use and ownership.

The interaction between legal ownership of land and the ability to protect the land is also the focus of Alston, Harris \& Mueller (2012) and Dye \& La Croix (2013, 2014). Alston et al. develop a model to investigate how de jure, de facto and enforcement of property rights interact during the early settlement periods. Applying their model to Australia, the United States, and Brazil, they show how frontiers settled between de facto to de jure property rights with the interaction between individuals (or groups) and the government. Dye \& La Croix (2013) also show how differences emerge in the adoption of property right institutions and how Spanish colonies lagged behind British colonies in this regard. They show how, despite earlier de jure 
property rights in Buenos Aires, the de facto property rights in New South Wales ultimately was more successful.

Dye \& La Croix (2014) expand the model by applying it to the colonial South African case. They conclude that, instead of following the path from de jure to de facto rights, a new system developed - the loan farm system. The loan farm system was a response to the declining threat of the Khoisan, the indigenous population present at the Cape when settlers arrived in the seventeenth century. They argue that the loan farm system evolved from a de facto to a de jure system because settlers made de facto claims outside the official boundary where they did not have the formal protection of de jure claims. The decline in the Khoisan population after a smallpox epidemic in 1713 spurred the Company to officially establish the new form of loan farms on the frontier and extract revenue from it, giving the de facto claims de jure rights as well.

This paper builds on Dye \& La Croix's model (2014) by applying empirical tools and an innovative combination of datasets to test whether the property right regime matter for individual outcomes, specifically the ability to trade on credit. NewtonKing (1999) and Fourie (2014) show that wealth levels at the Cape were high, but both ignore debt and credit transactions. Swanepoel \& Fourie (2018) have used these transactions to show the extent and nature of credit transactions at the Cape. They study the development of the monetary system, what type of collateral was used for debt and what characteristics of individuals were important for debt transactions. They found that debt and the number of debt transactions were good proxies for the relative wealth of the individual. We exploit this dataset of credit transactions even further to identify differences in the economic outcomes of the two property rights regimes at the Cape. We use the different types of property recorded in the probate inventories and debt to test whether property rights had any impact on debt transactions.

In a detailed study on the relationship between property rights and debt, Feder \& Feeny (1991) suggest land is only valuable as collateral where uncertainty and asymmetric information is absent with regard to the rights on the land. In the Alston et al. (2012) model, this would make land valuable for debt transactions where the de facto and de jure specification and enforcement of property rights are the same. The descriptive evidence we report below suggests that freehold farms, with more secure de jure property rights, had more debt. If the theory that only well-defined de jure and de facto property rights make land valuable for trading, it would imply that freehold farms with more debt had more secure de facto property rights.

The main concern with such descriptive evidence and the evidence presented by historians is endogeneity. Our contribution is to make use of an instrumental variable 
to remove reverse causality and to test if the differences in the de jure and de facto property rights of freehold and loan farms had an impact on economic activity or, in our case, debt transactions. We use being the eldest son as an external and random event to possessing a freehold farm. In the patriarchal society of the Cape, eldest sons were favoured to inherit freehold farms despite the Roman-Dutch law for equal inheritance between children. Our results from this instrumental variable approach support the existing historical literature which suggests that, despite the large de jure difference between the two systems, the property right ensconced in the loan farms system were viewed similarly to those of the freehold system.

These results contribute to the wider literature on property rights and its impact on economic outcomes. The lack of support for a strong correlation between de jure rights and debt supports scholars like De Soto (2001), who emphasises social norms and observed property rights rather than de jure claims. Our results thus provide more nuance to classic institutional and growth theory which propose that de jure property rights are always and everywhere a necessary if not sufficient component of economic growth.

\section{The land policies at the Cape}

When the Cape was first settled by Europeans in 1652, the plan was not for it to become a settlement colony. The Company wanted the Cape to serve as a refreshment station to passing ships between Europe and Asia. Because of the high demand for fresh produce and an inability to increase supply sufficiently, the Company released nine employees to become freehold farmers around the Liesbeeck River in Cape Town, only five years after arrival.

The vision of Company commander, Jan van Riebeeck, was small-scale farming, modelled on the European example. The plan soon failed. The crops brought with the settlers from Europe were unsuited for the soil and weather patterns of the Cape. More territory was needed. Under Governor Simon van der Stel, European settlement expanded toward the fertile mountainous region of Stellenbosch and the surrounding regions. Here, farmers could claim any land cultivated within three years. These initial claims were mostly given to settlers in freehold - the only requirement for settlers to relinquish one-tenth of the annual grain produced as a tax to the Company in Cape Town (Duly, 1968: 14). Many of these freehold farmers became known as the 'landed gentry'. The nature and size of these freehold farms made them more tradable and the prices of freehold farms increased throughout the period (Guelke, 1989: 79). 
Although the soil quality ${ }^{2}$ would certainly have differed between the farms, most had access to a river (Guelke \& Shell, 1983). Due to the unavailability of suitable soil in the region, the freehold farm system was terminated to new claims in 1717, although settlers did continue to trade and inherit these freehold farms well after 1717 (Newton-King, 1999: 18).

The second, and after 1717, most used form of property at the Cape was loan farms. Loan farms were obtained with relative ease: they were simply loaned from the Company for three, six or twelve months at a fixed rate, the size determined by riding half-an-hour on horseback in each direction. Duly (1968: 15) notes: 'the system was a form of legalized squatting'. The only parts of loan farms which could legally be sold were the fixed improvements; settlers thus had no de jure rights to the land they lived on under the loan farm system, but de facto settlers saw these loan farms as their property.

But, like other colonial land systems, de facto rights often evolved into de jure rights. Guelke (1976: 31) argues that '...[i]n practice there was little distinction between freehold land and leeningsplaatsen (loan farms). ${ }^{3}$ In fact, he goes further by saying '...the leases became so secure that the fixed improvements (which could be sold) came to reflect the value of the whole property'. Newton-King (1999: 99), in the most authoritative contribution to the history of the Cape frontier, submits the loan farms were similarly secure as the freehold farms. It is also evidence like this used by Dye \& La Croix to conclude that the loan farm system was a unique system that developed from de facto rights to de jure rights.

Before we continue to compare the freehold and loan farms systems in terms of property rights, a note here on the colonial expansion and land alienation. The Khoisan offered little resistance to Europeans seizing their land. Their nomadic lifestyle gave the Europeans easy access to land often claimed as uninhabited from the Khoisan. Skirmishes between the groups often resulted in the Khoisan conceding land in order to keep cattle and sheep obtained from the Europeans. Trade between

\footnotetext{
${ }^{2}$ Although farm size, soil quality and distance from Cape Town certainly matter, these are difficult to control for various reasons. Farm size is not recorded specifically in the probates or if there is mention of the size, it is the Company's prescribed 60 morgen. Land demarcation and the mapping of farms only happened in the midnineteenth century. Soil quality is also difficult to control for since the exact geographic location of the farms are unknown, which is also the reasons it is not possible to control for the distance from Cape Town. The descriptions are often vague, for example, 'next to a river', or 'in the district of', where districts often covered large areas.

${ }^{3}$ It should be noted here that the loan farms system at the Cape was similar to the Dutch system of the sixteenth century. De Vries \& Van Der Woude (1997:161-162) found the tenants in the Netherlands had strong legal support and it was often difficult for owners to replace tenants. They state that 'tenants acquired de facto permanent possession while the owners held nothing more than an old right to collect a fixed money rental.' Mitchell (2008 Chapter 3, p.4) calls the 'loan farm system a remnant of Dutch feudal land tenure practice.'
} 
the Europeans and the Khoisan inevitably impoverished the Khoisan, and many were later forced to work on the European farms to survive. The number of Khoisan in the colony also declined after outbreaks of smallpox in 1713 and 1755 and forced many tribes to move inland (De Villiers, 2012: 47). The colonial expansion was only halted when the European expansion toward the east was halted by the isiXhosa speaking tribes in the early nineteenth century, who were more numerous and had better weapons technology than the Khoisan (Fourie \& von Fintel, 2010).

A concern in comparing the de facto and de jure property rights in an economic context would be the strength of the de jure property rights, especially for the loan farms. The Company in de jure terms had the rights to reclaim loan farms if the annual rent was not paid, while they could not do the same with the freehold farms. Gie (1963: 153) postulates that this rarely happened and says farms would only be claimed by the Company if they wanted to establish a town in the area. In such a case, the farmer was also fully compensated for the land. The Company also did not act on the de jure rights of the loan farms, as there were large arrears for these farms at the start of the nineteenth century. Only after the second take-over by the British government in 1806 did land and taxation become a significant priority for the government (Duly, 1968: 61; Newton-King, 1999: 147).

In comparing the two systems, Guelke (1976) concluded that the freehold farms were more valuable because of their relative proximity to Cape Town. ${ }^{4}$ The value of these freehold farms spurred settlers to protect their farms as best they could. The Company initially provided ample military protection to freehold farmers, but as the frontier expanded and the threat from the Khoisan ebbed, farms, especially loan farms, enjoyed less protection (Fourie et al., 2013). Although this protection was linked to the threat of Khoisan retaliation, it inevitably also included the protection against other settlers.

The freehold and loan farms were clearly distinct in their de jure property rights. The freehold farms de jure enjoyed more secure property rights - they were tradable and inheritable - while the loan farms were not. However, some historians suggest that the de facto property rights of loan farms were similar to those of the freehold farms. We attempt to empirically test these assumptions here. Our main hypothesis is that the freehold farms enjoyed more secure property rights relative to the loan farms. If the freehold farms were more secure, we would expect them to be more valuable and therefore used more frequently as collateral for credit transactions. ${ }^{5}$ It is our new

\footnotetext{
${ }^{4}$ See footnote 1 on controlling for distance from Cape Town.

${ }^{5}$ Refer to footnote 1 on problems with the measurement of land for economic value, like water rights and soil quality. Without precise geographic data on these farms, we cannot control for these variables. Some information exists on the area of some of these farms, but not to the extent found in the probate inventories and less on the loan farms than the freehold farms. Surveys and information on these farms were more accurately
} 
combination of datasets which allows us to empirically test these hypotheses and historical descriptions to offer new insights into the role of property rights at the Cape.

\section{The freehold and loan farm data}

The data we use for our analysis comes from two sources: genealogical records and probate inventories. Both of these sources range over the entire eighteenth century, with the genealogical records continuing well after that. The genealogical records are familial lists from the first settlers with information on birth, marriage and death dates, as well as occupations. ${ }^{6}$ Our main variables of interest from the genealogies are whether someone was the eldest son, the number of children and the age of individuals. The second dataset, the probate inventories, list all the assets and debts of an individual at the time of death. The probate inventories are also known as the MOOC 8 series. Although not without bias, Schuurman (1980) concluded that they '.. enable the study of property according to occupation, age, and the number of children'. Cape Colony historians have also used them extensively. Newton-King (1999) used them to study the material life on the frontier. On wealth of the farmers of the Cape, Newton-King (1994) found poor farmers were in the minority and Fourie (2013) found the general wealth levels of settlers were 'remarkable'. These inventories were captured from early settlement to 1834 .

The main concern for bias in probate inventories is the exclusion of poor individuals, females and the young. Because our analysis is focused on land ownership, the poor are likely excluded. The Orphan Chamber inventories also exclude the wealthiest individuals at the Cape, as they would have drawn up private testaments and wills which are not captured by the Orphan Chamber. Fourie (2013) compared the probate records used here to Stellenbosch probate inventories collected by Krzesinkski-De Widt (2002). The Stellenbosch inventories are significantly more affluent than the Orphan Chamber inventories since these were collected specifically for individuals without a will or where heirs were minors. Females are also excluded from the study because our instrument of choice is being the eldest son and the comparison is between eldest sons and sons born later. Age is not a concern either. Swanepoel (2017) has shown there is very little differences and no correlation between age and debt levels, while we later also show there are no significant differences in the distribution or level of ages between eldest sons and sons born later.

captured toward the start of the nineteenth century and the British colonial period at the Cape, but not for this early period studied in the paper.

${ }^{6}$ For detailed information on how the genealogies were compiled and can be used in economic and demographic studies, see Cilliers \& Fourie (2014). 
We match the probate inventories to the genealogies. This may introduce an additional type of selection bias. Swanepoel \& Fourie (2018) offer an in-depth discussion of the differences and possible biases between the matched and unmatched sample. Their main conclusion is that the matched sample does not suffer from a strong bias in either direction of the wealth distribution, excluding both the poorest and richest in society. There is also no specific evidence that the younger siblings were systematically excluded from the probate inventories. Many examples exist of both eldest and younger siblings, like brothers Roelof (MOOC8/28.52) and Wynand Van Wijk (MOOC8/36.23). Roelof Van Wijk was the eldest child and first son of Wynand Willemsz Van Wijk and Magdalena Johanna Theunissen, while Wynand was their second son and sixth child.

The inventories offer information on the real estate owned, the policy under which this real estate was owned and in some cases the value and size of these farms. More detailed descriptions on farms include the policy under which the farm was obtained from the Company. We focus on two policies observed most in the inventories: freehold farms (eigendom, erfgrondbrief or transport) and loan farms (leeningsplaats, in leening). ${ }^{7}$ Some inventories listed both types of farms, like Josua Joubert (MOOC8/21.32) who owned one farm Welbedagt, situated in Wagenmakers Vallei in the Stellenbosch District. The farm was owned in freehold when he died in 1795. He also owned two loan farms, one Elands Jagt situated next to Molenaars Rivier in du Toits Kloof and another named Varkens Kop situated in the Sneeuberge. Table 1 provides a summary of the information available on land ownership from these inventories.

Table 1: Descriptive statistics on land/farms owned, with and without policies

\begin{tabular}{|c|c|c|c|c|c|c|}
\hline Property Category & $\begin{array}{c}\text { Number of } \\
\text { farms }\end{array}$ & $\%$ & $\begin{array}{c}\text { Farms } \\
\text { with } \\
\text { known } \\
\text { policies }\end{array}$ & $\begin{array}{c}\% \\
\text { Farms } \\
\text { with } \\
\text { known } \\
\text { policies }\end{array}$ & $\begin{array}{l}\text { Loan } \\
\text { farms }\end{array}$ & $\begin{array}{l}\text { Freehold } \\
\text { farms }\end{array}$ \\
\hline No land & 1135 & 54.15 & - & & - & - \\
\hline One Farm & 621 & 29.63 & 362 & 64.64 & 272 & 90 \\
\hline Two Farms & 209 & 9.97 & 127 & 22.68 & 95 & 32 \\
\hline Three Farms & 58 & 2.77 & 33 & 5.89 & 19 & 14 \\
\hline Four and more farms & 73 & 3.48 & 38 & 6.79 & 15 & 23 \\
\hline Total & 2096 & 100 & 560 & 100 & 401 & 159 \\
\hline
\end{tabular}

Source: Probate inventories matched to genealogical records. Period: 1673 - 1834

\footnotetext{
${ }^{7}$ Another form quitrent (erfpagt) was observed, but only 60 are found in the inventories. These were mainly loan farms which were converted to freehold farms. Their tenure was closer to that of the freehold farms and we, therefore, include them as freehold farms. The results remain whether these are included or excluded.
} 
Almost 54\% of the inventories did not list any land. Looking at the other indicators of wealth, we find further evidence of left truncation. Table 2 also provides summary statistics on the outcome of interest, the value of debt at death by type of property right. It also records credit, whether an individual had both credit and debt, and the total number of bonds observed in the inventories and other household characteristics. The two groups excluded from the analysis below are the individuals with no land listed, and the individuals where farms are listed, but the type of property right regime is unknown. The individuals included are thus either those with loan farms or freehold farms listed.

Table 2: Descriptive statistics of variables of interest by land ownership policies

\begin{tabular}{|c|c|c|c|c|c|}
\hline \multicolumn{6}{|c|}{ No Land } \\
\hline & Obs. & Mean & Std. Dev. & Min & Max. \\
\hline Number of farms & 755 & - & - & - & - \\
\hline Number of slaves & 755 & 1.38 & 3.38 & 0 & 36 \\
\hline Value of debt & 755 & 367.94 & 1275.19 & 0 & 20167 \\
\hline Value of credit & 755 & 691.69 & 5612.89 & 0 & 103424 \\
\hline Married & 755 & 0.76 & 0.42 & 0 & 1 \\
\hline Number of children & 755 & 3.12 & 3.75 & 0 & 19 \\
\hline \multicolumn{6}{|c|}{ Farms with unknown policies } \\
\hline & Obs. & Mean & Std. Dev. & Min & Max. \\
\hline Number of farms & 281 & 1.73 & 1.27 & 1 & 9 \\
\hline Number of slaves & 281 & 7.77 & 10.59 & 0 & 73 \\
\hline Value of debt & 281 & 3732.94 & 12594.28 & 0 & 135755 \\
\hline Value of credit & 281 & 4297.27 & 17754.66 & 0 & 150775 \\
\hline Married & 281 & 0.87 & 0.34 & 0 & 1 \\
\hline Number of children & 281 & 3.01 & 3.49 & 0 & 16 \\
\hline \multicolumn{6}{|c|}{ Loan Farms } \\
\hline & Obs. & Mean & Std. Dev. & Min & Max. \\
\hline Number of farms & 259 & 1.47 & 0.90 & 1 & 8 \\
\hline Number of slaves & 259 & 5.68 & 7.75 & 0 & 45 \\
\hline Value of debt & 259 & 2318.19 & 6967.87 & 0 & 85922 \\
\hline Value of credit & 259 & 1076.98 & 5945.41 & 0 & 92246 \\
\hline Married & 259 & 0.80 & 0.40 & 0 & 1 \\
\hline Number of children & 259 & 4.34 & 4.27 & 0 & 23 \\
\hline \multicolumn{6}{|c|}{ Freehold farms } \\
\hline & Obs. & Mean & Std. Dev. & Min & Max. \\
\hline Number of farms & 113 & 2.06 & 1.72 & 1 & 12 \\
\hline Number of slaves & 113 & 9.81 & 10.26 & 0 & 60 \\
\hline Value of debt & 113 & 2875.35 & 5414.77 & 0 & 35197 \\
\hline Value of credit & 113 & 5444.71 & 27661.71 & 0 & 256425 \\
\hline Married & 113 & 0.90 & 0.30 & 0 & 1 \\
\hline Number of children & 113 & 4.26 & 4.19 & 0 & 16 \\
\hline
\end{tabular}


The individuals with no land listed were by far the poorest, but by no means excluded from debt transactions. They owned on average 1 slave, while the individuals in the other categories owned more than 5 slaves on average. The mean value of debt for these individuals are $368 \mathrm{rds}$, while the credit value was even higher at $692 \mathrm{rds}$. More than three quarters were married (lower than the other groups) and they had an average of 3.12 children. Because we have no information on their real estate, either because they did not own any or because their land was not recorded in the inventories, we exclude these individuals from the analysis. Although this is a serious concern when we want to analyse the average level of wealth in the Colony, our purpose here is more focused: we only aim to compare those who own freehold versus loan farms. This exclusion, therefore, does not bias our results.

The second group of individuals excluded from the analysis below are those with some farms, but where we do not observe the policy under which this land was owned. They look similar to those with freehold farms - if not slightly richer. They own more slaves than the loan farm individuals, but less than freehold farmers. They have the highest debt of all the groups, but less credit than the freehold individuals. Although the ideal would have been to include them in the analysis, because we cannot code their respective property regime, we exclude them from the analysis.

In short, our summary statistics clearly show that the freehold farmers are wealthier than their loan farm counterparts. ${ }^{8}$ They have on average more land, slaves, debt, and extended more credit. Guelke \& Shell (1989), Fourie \& von Fintel (2010) and Dooling (2005) attribute the disparities in wealth to the landed gentry - owners of many freehold farms and slaves. These authors also suggest that it was the gentry that often supported the poorer farmers with loans. The differences between the groups of property owners are less pronounced when we consider the portion who were married and the average number of children. Because our analysis is focused on debt, Figure 1 shows the different natural logarithm distributions of debt for these two groups of property owners. These distributions support the historical narrative that claims the freehold farmers were wealthier than the loan farmers. The freehold farms' mean and median are to the right of the loan farms'. The correlation between land ownership and debt is the focus of the next section.

\footnotetext{
${ }^{8}$ If individuals owned both freehold and loan farms, we add them to individuals with freehold farms, because freehold farms were more scarce and valuable. Our results are robust whether we include these observations or not.
} 


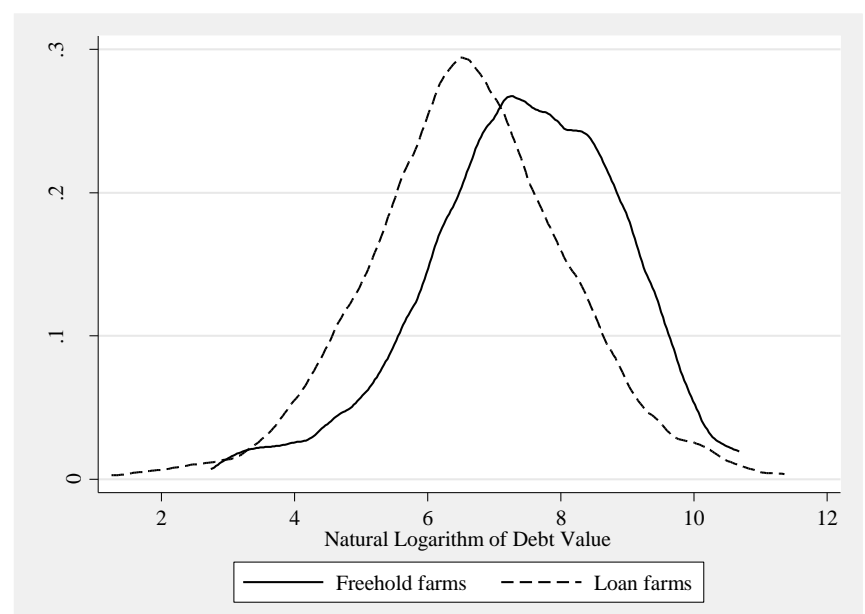

Notes: Kolmogorov-Smirnov test for equality of distributions: $p$-value $=0.0000$. We reject the hypothesis that the distributions are equal at the $5 \%$ significance level.

\section{Figure 1: Debt distributions of freehold and loan farms}

Source: Own calculations, probate inventories

\section{Correlations between land ownership and debt}

The descriptive statistics from the probate inventories suggest freehold farms were owned by the more affluent individuals of the Cape. Before we test the hypothesis that freehold farms (with more secure property rights) had more debt, we first focus on simple OLS regressions between land ownership and debt. We study the correlation between the number of farms and debt, and then compare the debt levels of individuals with at least one freehold farms and those with at least one loan farms.

We include controls for other wealth variables - the number of slaves owned, whether the individual was married and their number of children. The number of slaves an individual owned had previously been by Guelke \& Shell (1989) and Fourie (2014) as a proxy for wealth. Swanepoel \& Fourie (2018) find a strong correlation between slave ownership and debt, and it remains an important alternative wealth indicator to the number of farms owned. We divide the number of slaves owned into groups as follows: 0 slaves, between 1 and 4 slaves, between 5 and 10 slaves and more than 10 slaves. ${ }^{9}$ If an individual was married it is likely they had access to more

\footnotetext{
${ }^{9}$ The results presented here are not sensitive to this grouping.
} 
credit due to network effects. ${ }^{10}$ Individuals with more children were more prosperous. This is expected; as new evidence by Cilliers (2015) shows, South Africa's fertility decline only happened with the mineral revolution of the late nineteenth century. We also control for a trend in the debt of freehold and loan farms. We do this because of the relatively fixed supply of freehold farms after 1717, while the supply of loan farms remained elastic. Figure 2 shows the debt growth of loan farms and freehold farms over the period, as well as the fitted trend lines. It is clear that the loan farm debts increased more toward the end of the century, while the debts of freehold farms grew at a constant pace. ${ }^{11}$

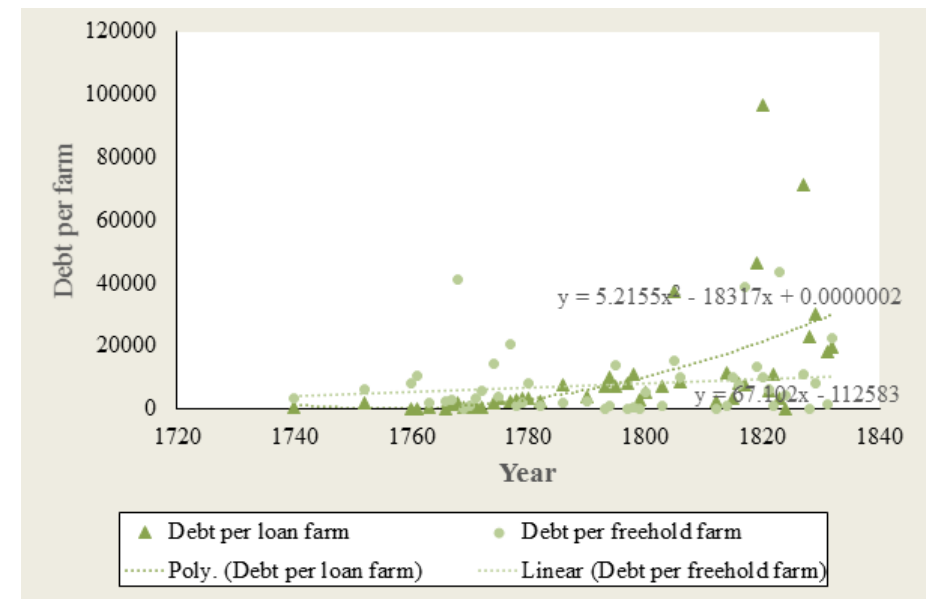

\section{Figure 2: Debt growth over time by policy}

Source: Own calculations, probate inventories, and genealogical records

Table 3 shows the differences in debt for individuals with freehold farms to loan farms. This is the first evidence that supports the hypothesis that the individuals with freehold farms were wealthier, had better-protected property rights and more debt. If an individual owned a freehold farm, their debt level was $36.58 \%$ higher than individuals who did not own freehold farms according to this correlation. Slave ownership continues to matter for the debt of freehold farmers and loan farms. Neither the marriage nor the number of children has a significant correlation with debt.

\footnotetext{
${ }^{10}$ Because debt in the probate inventories does not distinguish between the debt of the wife or husband, it is safe to assume that both have the responsibility to repay these debts.

${ }^{11}$ Ideally, we would like to do robustness checks for smaller periods as well, but the current sample size does not allow for this.
} 
Table 3: OLS regression between debt of freehold and loan farms

\begin{tabular}{lr|r}
\multirow{2}{*}{ Dependent variable: } & \multicolumn{2}{c}{ Natural logarithm of individual debt, 1673- 1834 } \\
\cline { 2 - 3 } & \multicolumn{2}{|c}{ Freehold farms } \\
\cline { 2 - 3 } & Coefficient & Std. error \\
\hline Farms owned under freehold policy & $0,3658^{* * *}$ & 0,1505 \\
Zero slaves (ref.) & $0,5241^{* * *}$ & \\
Between 1 and 4 slaves & $1,0333^{* * *}$ & 0,1738 \\
Between 5 and 10 slaves & $1,7380^{* * *}$ & 0,1867 \\
More than 10 slaves & 0,0108 & 0,2202 \\
Married & $-0,0176$ & 0,1870 \\
Number of children in the household & YES & 0,0156 \\
Control for trend & $5,5862 * * *$ & 0,2096 \\
Constant & \multicolumn{2}{|c}{463} \\
\hline N & \multicolumn{2}{|c|}{0,2394} \\
R-squared & \multicolumn{2}{|c|}{} \\
\hline
\end{tabular}

The dependent variable is the natural logarithm of an individuals debt level. The farms owned under freehold is a dummy variable: 1 if any farm was owned under freehold, 0 if loan farms were listed on the inventory. The slave groups are the reference to those with no slaves. Married is 1 if the individual was married at the time of death, and the number of children is recorded from the genealogical records. Significance levels: * $10 \%, * * 5 \%$ and $* * * 1 \%$.

These estimated impacts point to different outcomes for freehold and loan farms, suggesting there was at least some role for property rights to play in determining the value of debt transactions. On first glance, the individuals with freehold farms were more prosperous and had more debt - supporting the hypothesis that they had betterprotected property rights. One concern with these correlations is reverse causality. Individuals with freehold farms have more debt because they had more collateral due to better property rights relative to individuals with loan farms. But the reverse is also true: Individuals with freehold farms may have had more debt because they used debt to purchase these farms in the first place. Therefore, the OLS regression results will be upwardly biased.

Another possible channel for freehold farms to have more debt is an income and revenue channel. The freehold farms may have been more profitable (and therefore have more access to credit) simply because they did not pay the rent the loan farmers were obliged to pay. We do not think this was the case for two reasons. First, the rents on the loan farms were often not collected. Second, the ratio between debt and the annual rent is too high to believe the rents were an obstacle to the credit market. The annual rent of 24 rds dwarfs in comparison with average debts of 2318 rds (Table 1). Next, we turn to address the reverse causality between debt and land ownership with the use of an instrumental variable. 


\section{An instrumental variable approach: Eldest son, debt and freehold farms}

Due to the possibility of reverse causality and endogeneity in estimating the effect of property right regimes on debt levels, we use an instrumental variable approach here to estimate the effect of owning a freehold farm on an individual's debt level. Our instrument of choice is being the firstborn son in a household relative to second, third or sons born later. Many studies have used the random variation of birth order to study different economic outcomes. These economic outcomes include schooling or returns to education (Black et al., 2005b), income (Kantarevic \& Mechoulan, 2006), labour market outcomes like employment (Black et al., 2005a) and the decision to migrate (Abramitzky et al., 2012). As far as we are aware, there have not been studies done using first-born sons and property rights.

To use an instrumental variable, we estimate a two-stage least squares regression where the first regression is related to the probability of a first-born son owning a freehold farm, and the second regression relating to the relationship between owning a freehold farm and the natural logarithm of individual debt. We also control for a vector of individual characteristics, which include our wealth measurements: slave ownership, whether an individual was married, the number of children and a trend in the growth of debt for the property types.

For our instrument to estimate the local average treatment effects (LATE), it should comply with the following four assumptions: independence (exogeneity), exclusion restriction, the first stage (relevance) and monotonicity assumptions (Angrist \& Pischke 2009: 153). The independence assumption requires that the instrument is randomly assigned. This means firstborn sons should not have an innate higher ability or another unobservable characteristic which makes them more likely to own a freehold farm. Although not directly testable, we do not think there is any reason to believe the eldest sons would be systematically better and more able to own freehold farms. The randomness of birth order, we believe, is sufficient to pass the independence assumption.

The exclusion restriction requires that birth order does not have a direct causal effect on the level of debt. In previous research (Swanepoel \& Fourie, 2018), it has been found that debt was a general occurrence at the Cape. The best way to support the exclusion restriction is to look at the debt distribution of the eldest sons versus sons born after. Figure 3 shows these distributions. Table 4 provide the t-test for the size of debts: there is no significant difference between the size of debt for eldest sons and sons born later. Since there is no significant difference in either distribution or size of debt for eldest sons to other sons, we assume there is no direct relationship 
between being the eldest son and his debt level. We would argue that being the eldest son satisfies the exclusion restriction.

Table 4: T-test of eldest son vs non-eldest sons, debt size, owning a freehold farm and age

\begin{tabular}{|c|c|c|c|c|c|c|}
\hline & \multicolumn{2}{|c|}{ Debt size } & \multicolumn{2}{|c|}{ Owned freehold farm } & \multicolumn{2}{|c|}{ Age } \\
\hline & $\mathbf{N}$ & Mean & $\mathbf{N}$ & Mean & $\mathbf{N}$ & Mean \\
\hline Not eldest son & 638 & 1535,01 & 169 & 0.1834 & 1152 & 48.6946 \\
\hline Eldest son & 681 & 1692,86 & 179 & 0.4302 & 1238 & 49.8334 \\
\hline Combined & 1319 & 1616,02 & 348 & 0.3103 & 2390 & 49.579 \\
\hline Difference & & $-156,79$ & & -0.2467 & & -2.4818 \\
\hline $\begin{array}{l}\text { t-stat } \\
\text { p-value }\end{array}$ & & $\begin{array}{l}411 \\
811\end{array}$ & & $\begin{array}{l}5,1443 \\
0,0000\end{array}$ & & $\begin{array}{l}4662 \\
427\end{array}$ \\
\hline
\end{tabular}

Source: Debt size and owned a freehold farm from probate inventories; age from genealogical records matched to probate inventories.

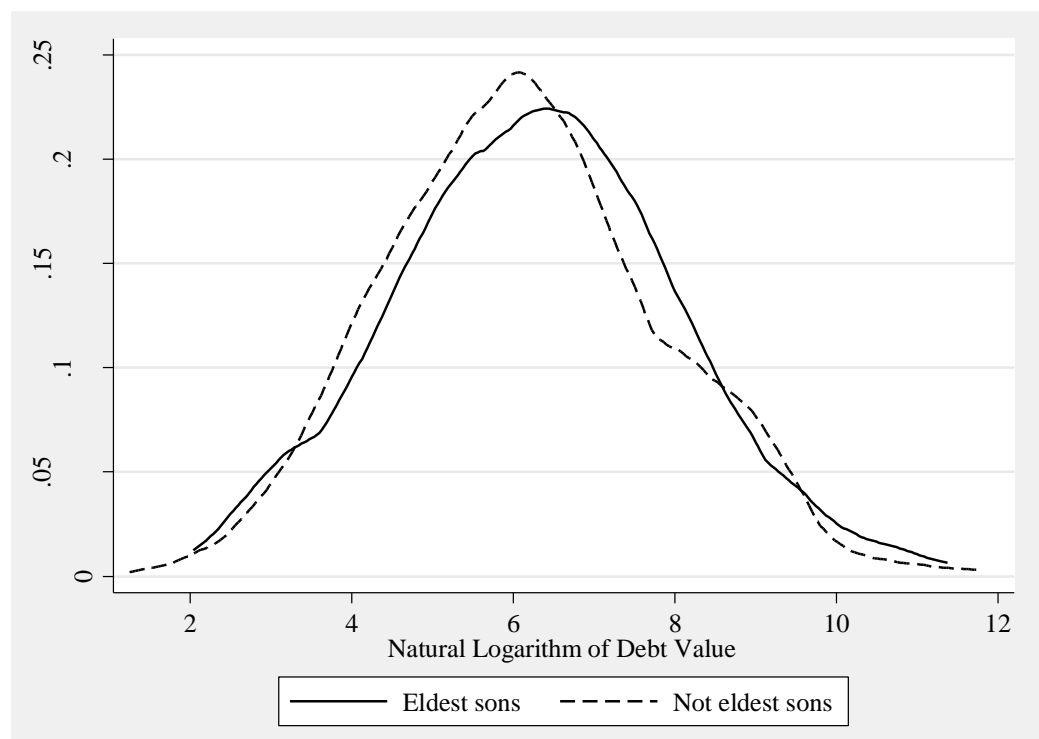

Notes: Kolmogorov-Smirnov test for equality of distributions: $p$-value $=0.134$. We cannot reject the hypothesis that the distributions are equal at the 5\% significance level.

Figure 3: Debt distributions for eldest and non-eldest sons

Source: Own calculations, probate inventories 
Two other channels through which the instrument may have an effect on individual debt are longevity and occupation. We observe both these variables from the genealogical records ${ }^{12}$ and match it to individuals in the probate inventories. For occupation, higher skilled occupations may present less risky borrowing and therefore the ability to obtain more debt. Firstborn sons may also have more opportunities to join these higher skilled occupations. The occupations we observe are divided into different skill levels: unskilled or low skills, farmers, medium skilled, highly skilled and professional. We run an ordered logit to test if there is a preference for eldest sons in higher skills categories (Table 5). The elder sons do not have a significantly larger share in more professional skills relative to sons born later.

Table 5: Ordered logistic regression for eldest and other sons

\begin{tabular}{l|lr|cr}
\cline { 2 - 5 } & \multicolumn{4}{c}{ Skill level } \\
\cline { 2 - 5 } & Coefficient & Std. error & Odds ration & Std. error \\
\hline First son & 0,1165 & 0,2182 & 1.1235 & 0.2451 \\
\hline $\mathbf{N}$ & \multicolumn{2}{|c|}{313} & 313 & \\
\hline
\end{tabular}

Source: Matched sample between genealogical records and probate inventories.

The second concern for the channel of our instrument may be longevity - individuals who were older when they died had longer to accumulate debt and real estate. Firstborn sons may also have longer longevity because of resources reverted to the eldest son rather than sons born later. However, we find no significant difference in the ages of eldest sons relative to sons born later. Eldest sons' expected age for the period (conditional on reaching 16 years) was 49.83 years, while sons born later lived an average of 48.69 years. Figure 4 shows the age distribution of eldest and non-eldest sons, while table 4 also shows the t-test for average ages between these two groups. Both these measures show no significant difference for the eldest sons and sons born later, the strongest evidence that being the firstborn son is an appropriate instrument.

For the first stage assumption, the eldest sons need to have a higher probability of owning a freehold farm. The system of inheritance at the Cape was one of partible inheritance derived from Roman-Dutch law. This meant the individual's estate was divided half to the spouse and the equally among the children. Most often the estate was sold in its entirety at auction and the proceeds distributed between the heirs. Despite this, anecdotal evidence has been provided by Newton-King (1994) and Dooling $(2005 ; 2007)$ that the eldest sons were favoured when it came to the inheritance of property and freehold farms. Newton-King (1994) suggested that older

\footnotetext{
${ }^{12}$ For more information on these records, see Cilliers (2015). She further provides information on which occupations are divided into which skill category.
} 
sons inherited the freehold farms, while sons born later inherited loan farms. Dooling (2005) and Dooling (2007) referred to how in this patriarchal society sons were inevitably favoured before daughters when it came to inheritance. ${ }^{13}$ With this anecdotal evidence at hand, we tested the likelihood of older sons owning more freehold farms and indeed found a higher probability among eldest sons of owning freehold farms, at $48 \%$, while of sons born later, only $18 \%$ owned freehold farms (also in Table 5).

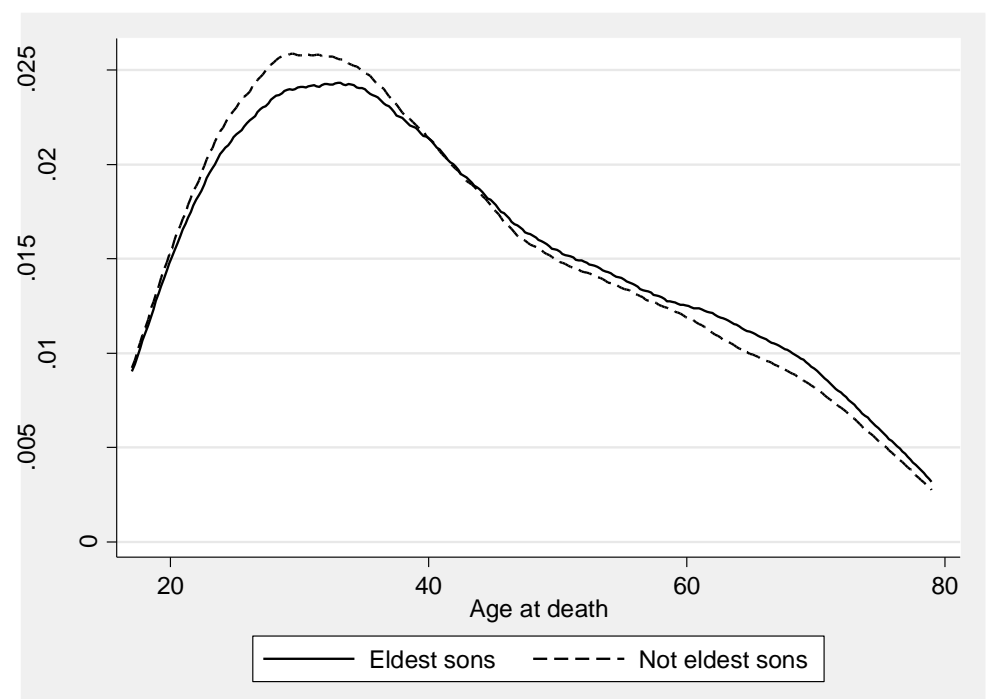

Notes: Kolmogorov-Smirnov test for equality of distributions: $\mathrm{p}$-value $=0.06$. We cannot reject the hypothesis that the distributions are equal at the $5 \%$ significance level.

\section{Figure 4: Age at death distributions for eldest and non-eldest sons}

Source: Own calculations, genealogical records

Finally, monotonicity requires that the instrument affects all the treated in the same direction, that is, being the eldest son will always make you more likely to own a freehold farm rather than less likely. The historical evidence presented above not only supports the first stage assumption, but also the monotonicity assumption. Eldest sons were always more likely to own farms relative to their brothers born later and not the reverse, across time and districts. ${ }^{14}$

\footnotetext{
${ }^{13}$ How the settlers bypassed the system and how firstborn sons managed to obtain the freehold farms remain unknown.

${ }^{14}$ We can investigate the location of the death of the eldest brother versus brothers born later in either data sources. However, the death locations are not also recorded.
} 
Being the firstborn son appears to be a valid instrument for the probability of having a freehold farm relative to sons who were born later. Table 6 presents the regression results for the instrumental variable estimation. The result supports the hypothesis that the eldest son had a $17 \%$ higher probability to have a freehold farm relative to sons born later, significant at the $1 \%$ level. Individuals with more slaves were also more likely to own freehold farms. Having a spouse listed on the inventory is also associated with higher probability of owning a freehold farm, but none of the other characteristics are associated with a higher probability of owning a freehold farm.

\section{Table 6: Regression results from instrumental variable analysis}

\begin{tabular}{|c|c|c|c|}
\hline \multicolumn{4}{|c|}{ PANEL A } \\
\hline \multicolumn{2}{|c|}{$\begin{array}{l}\text { First-stage regression } \\
\text { Owned a freehold }\end{array}$} & \multicolumn{2}{|c|}{$\begin{array}{l}\text { Second Stage Regression } \\
\text { Ln(Debt Value) }\end{array}$} \\
\hline First son & $\begin{array}{r}0,1735 * * * \\
0,0516\end{array}$ & Owned a freehold farm & $\begin{array}{l}0,1907 \\
0,9984\end{array}$ \\
\hline 0 Slaves & (ref,) & 0 Slaves & (ref,) \\
\hline Between 1 and 4 slaves & $\begin{array}{r}0,1411 * * \\
0.0710\end{array}$ & Between 1 and 4 slaves & $\begin{array}{l}0,1674 \\
0.2658\end{array}$ \\
\hline Between 5 and 10 slaves & $\begin{array}{r}0,2221 * * * \\
0,0708\end{array}$ & Between 5 and 10 slaves & $\begin{array}{r}0,8850 * * \\
0,3316\end{array}$ \\
\hline More than 10 slaves & $\begin{array}{r}0,3738 * * * \\
0,0750\end{array}$ & More than 10 slaves & $\begin{array}{r}1,6309 * * * \\
0,4571\end{array}$ \\
\hline Married & $\begin{array}{r}0,1913^{*} \\
0,0805\end{array}$ & Spouse listed on inventory & $\begin{array}{r}-0,09908 \\
0,3855\end{array}$ \\
\hline Children & $\begin{array}{r}-0,0087 \\
0,0066\end{array}$ & Children & $\begin{array}{r}-0,0078 \\
0,0256\end{array}$ \\
\hline Trend control & YES & & YES \\
\hline Constant & $\begin{array}{r}-0,0979 \\
0,0845\end{array}$ & Constant & $\begin{array}{r}6,2289 * * * \\
0,2747\end{array}$ \\
\hline $\begin{array}{l}\mathrm{N} \\
\mathrm{F}(7,287)\end{array}$ & $\begin{array}{r}278 \\
11,30 \\
\end{array}$ & & \\
\hline
\end{tabular}

The dependent variable is the natural logarithm of an individuals debt level. The farms owned under freehold is a dummy variable: 1 if any farm was owned under freehold, 0 if loan farms were listed in the inventory. First son is a dummy variable for being the firstborn son (eldest son) in the family and is zero if it is sons born later. The slave groups are the reference to those with no slaves. Married is 1 if the individual was married at some point, and the number of children is recorded from the genealogical records. The decrease in observations is due to not all the individuals who owned land was identified in the genealogical records from which the eldest sons were identified. The F-statistic is larger than 10, consistent with a strong instrument for the Staiger-Stock (1997) rule of thumb (10) for exactly identified two-stage least squares. See text for more details.

Significance levels: $* 10 \%, * * 5 \%$ and $* * * 1 \%$, standard errors below coefficient.

Source: Probate inventories, own calculations. Dependent on son reaching 16 years of age. 
The second stage regression, however, reveals that, given the instrumental variable of a being the eldest son, owning a freehold farm does not matter for the individual's debt level. ${ }^{15}$ Although the coefficient on freehold farms are positive, the effect is less than half of the estimates in the OLS regression and turns insignificant. This suggests that owning a freehold farm with more secure de jure property rights did not matter for debt transactions. In the property right framework sketched in section 2 , the debt market at the Cape considered the de facto property rights of land more important for transactions. This supports the historiography of the Cape in which authors like Guelke (1989) and Newton-King (1999) who have provided evidence that the property rights of freehold farms were similar to the loan farms. It also advances the international literature, by focussing on microeconomic information and the recent literature which suggest social norms and de facto rights are important when de jure rights are established.

For our other variables of interest, the higher groups of slave ownership have a significant effect on debt, suggesting the slaves was an important aspect of access to debt at the Cape. ${ }^{16}$ The spouse and number of children in the household remain insignificant for debt levels. Given that property rights seemed not to matter and the only significant impact comes from slaves, it provides support for the recent literature on early credit markets. This literature postulates that credit and debt were not more frequently used by poor, as suggested before, but by those with the greatest assets (e.g., Muldrew, 2012; Ogilvie et al., 2012).

The Cragg-Donald Wald statistic (12.50) is larger than the rule of thumb test of 10 (Staiger \& Stock, 1997). This suggests that the instrument passes the weak instrument test, even with a just-identified regression. ${ }^{17}$

Before we discussed that individuals, who owned land, but of which the policy is uncertain would be excluded (p.45). As a robustness check, we include these individuals as freehold farms. These individuals according to the descriptive statistics are closer in debt and wealth to the individuals with freehold farms. The results remain the same. Firstborn sons are still $17 \%$ more likely to own a freehold farm, while the second stage regression show an increase to the coefficient of owning a freehold farm, it does not reach the levels of the OLS regression. In fact, it is still $40 \%$ lower than the OLS regression. When these individuals are included, the two

\footnotetext{
${ }^{15}$ The debt on a farm was not inherited with the fixed property, but all debts of the estate was repaid before any inheritance by children were received.

${ }^{16}$ For more information on the significance of slaves and the credit market at the Cape, see Swanepoel \& Fourie, (2018).

${ }^{17}$ Because we only have one endogenous regressor and one instrument, the specification is just identified. Other tests like AR and Kleinbergen Paap do not allow for just identified regressions and cannot be performed here.
} 
stage-least squares regression becomes more precisely estimated. These results are presented in Table 7.

Table 7: Regression results from instrumental variable analysis including unknown property

\begin{tabular}{|c|c|c|c|}
\hline \multicolumn{4}{|c|}{ PANEL A } \\
\hline \multicolumn{2}{|c|}{$\begin{array}{l}\text { First-stage regression } \\
\text { Owned a freehold }\end{array}$} & \multicolumn{2}{|c|}{$\begin{array}{l}\text { Second Stage Regression } \\
\text { Ln(Debt Value) }\end{array}$} \\
\hline First son & $\begin{array}{r}0,1658 * * * \\
0,0431\end{array}$ & Owned a freehold farm & $\begin{array}{l}0,2499 \\
0,8174\end{array}$ \\
\hline 0 Slaves & (ref,) & 0 Slaves & (ref,) \\
\hline Between 1 and 4 slaves & $\begin{array}{l}0,0903 \\
0,0592\end{array}$ & Between 1 and 4 slaves & $\begin{array}{l}0,0360 \\
0,1962\end{array}$ \\
\hline Between 5 and 10 slaves & $\begin{array}{r}0,1207 * * \\
0,0609\end{array}$ & Between 5 and 10 slaves & $\begin{array}{r}0,7594 * * * \\
0,2162\end{array}$ \\
\hline More than 10 slaves & $\begin{array}{r}0,2354 * * * \\
0,0685\end{array}$ & More than 10 slaves & $\begin{array}{r}1,5500 * * * \\
0,2738\end{array}$ \\
\hline Married & $\begin{array}{r}0,2440 * * * \\
0,0684\end{array}$ & Spouse listed on inventory & $\begin{array}{r}-0,1484 \\
0,3145 \\
\end{array}$ \\
\hline Children & $\begin{array}{r}-0,0263 * * * \\
0,0058\end{array}$ & Children & $\begin{array}{r}-0,0128 \\
0,0313\end{array}$ \\
\hline Trend control & YES & & YES \\
\hline Constant & $\begin{array}{l}0,2725 \\
0,0733\end{array}$ & Constant & $\begin{array}{r}6,3743 * * * \\
0,3634\end{array}$ \\
\hline $\begin{array}{l}\mathrm{N} \\
\mathrm{F}(7,287)\end{array}$ & $\begin{array}{r}508 \\
14,76\end{array}$ & & \\
\hline
\end{tabular}

The dependent variable is the natural logarithm of an individuals debt level. The farms owned under freehold is a dummy variable: 1 if any farm was owned under freehold or if the policy of the property is unknown, 0 if loan farms were listed in the inventory. First son is a dummy variable for being the firstborn son (eldest son) in the family and is zero if it is sons born later. The slave groups are the reference to those with no slaves. Married is 1 if the individual was married at some point, and the number of children is recorded from the genealogical records. The decrease in observations is due to not all the individuals who owned land was identified in the genealogical records from which the eldest sons were identified. The F-statistic is larger than 10, consistent with a strong instrument for the Staiger-Stock (1997) rule of thumb (10) for exactly identified two-stage least squares. See text for more details.

Significance levels: $* 10 \%, * * 5 \%$ and $* * * 1 \%$, standard errors below coefficient.

Source: Probate inventories, own calculations. Dependent on son reaching 16 years of age.

The freehold and loan farms had distinct formal processes for claims and legal specifications differed. Despite the differences in de jure property rights, the economic outcomes, measured here by the value of debt transactions, for the two systems do not show any differences. The fact that our instrumental variable regressions show much lower estimates on the effect of having a freehold farm rather 
than owing a loan farm suggests that de facto property rights, not de jure property rights, were more important for for economic decision-making. ${ }^{18}$ Like De Soto and Lamoreaux suggested, the local conditions under which the property right regime is observed seems to trump the formal property right system that is promulgated. In the case of the Dutch Cape Colony, the settlers' view was that the loan farms were as secure in their property rights as the freehold farms.

\section{Conclusion}

For any economic transaction to take place, well-defined and well-enforced property rights are required. Economists suspect that property right regimes are rooted in the history of the region, but it has been difficult to prove the outcome of this on economic development empirically. We do this by investigating property rights' role in the debt market of the Cape Colony. The Cape offers an alternative to the development of de jure and de facto property rights. At the Cape, property rights of loan farms were developed from de facto property rights to de jure property rights, while other case studies like the United States, Australia and Brazil developed from de jure property rights to de facto property rights. The two land tenure systems, freehold and loan farms enabled us to study individuals with the different types of property and to compare them one another. The contribution of this research has been to focus on a microeconomic outcome, individual debt levels, rather than macroeconomic outcomes.

Economic theory would suggest land is only valuable for debt transactions if there is no asymmetry and uncertainty regarding land rights. Historians of the Cape have suggested the de facto property rights of the loan farms were the same and as secure as the freehold farms, even though the de jure rights between the systems differed. Our hypothesis is that individuals with freehold farms had more secure de jure property rights and freehold farms should, therefore, be more valuable for debt transactions. On this basis, individuals with freehold farms should have more debt. The descriptive statistics certainly supported this hypothesis; individuals with freehold farms had higher correlations with debt relative to individuals with loan farms or individuals with no farms. However, after accounting for endogeneity concerns regarding the relationship between debt and land rights, the significance of owning a freehold for debt transactions disappears. We tested the assumption by using an instrument of the eldest son, who had a higher probability of owning a freehold farm. Our results provide empirical evidence for what historians have suspected: that the institution of property right depends on the society in which it is

\footnotetext{
${ }^{18}$ To further investigate the positive coefficient, would require further information unavailable at the time of writing. This could include the type of farming activities between loan farms and freehold farms, or the profitability of these farms.
} 
embedded. Instead of formal de jure rights, how rights are perceived and used by individuals (de facto) is likely to have a bigger influence on economic transactions.

Property rights remain important for economic growth and development, but more recent research has started to show that it is more complex - the local conditions also matter. We gave another example, here, of how local conditions and how these rights are perceived matters as well. Besley (1995) said, '...formal (de jure) rights might have very little to do with the ability to exercise these rights (de facto). ' If the answer of institutional economics is to give de jure property rights in land to individuals, without taking into account the local de facto conditions, property rights might not lead to the expected gains in economic growth. Schlager \& Ostrom (1992) already called for an investigation into "how various types of institutional arrangements perform comparatively when confronted with similarly difficult environments'. In line with the literature, we attempt to show the perception of property rights at the Cape, or the de facto mattered more than de jure property rights delineated by laws.

\section{References}

Abramitzky, R., Boustan, L.P. \& Eriksson, K. 2013. 'Have the poor always been less likely to migrate? Evidence from inheritance practices during the Age of Mass Migration', Journal of Development Economics, 102, 2-14.

Acemoglu, D., Johnson, S. \& Robinson, J.A. 2001. 'The colonial origins of comparative development: An empirical investigation', American Economic Review, 91(5), 1369-1401.

Alston, L.J., Harris, E. \& Mueller, B. 2012. 'The development of property rights on frontiers: Endowments, norms, and politics', Journal of Economic History, 72(3), 741-770.

Angrist, J.D. \& Pischke, J-S. 2009. Mostly harmless econometrics. Princeton University Press, Princeton, NJ.

Austin, G. 2005. Labour, land, and capital in Ghana: From slavery to free labour in Asante, 18071956. University of Rochester Press, Rochester, NY.

Banerjee, A. \& Iyer, L. 2005. 'History, institutions, and economic performance: The legacy of colonial land tenure systems in India', American Economic Review, 95(4), 1190-1213.

Besley, T. 1992. 'Property rights and investment incentives', Journal of Political Economics, 103(5), 903-937.

Black, S.E., Devereux, P.J. \& Salvanes, K.G. 2005a. From the cradle to the labor market? The effect of birth weight on adult outcomes. NBER Working Paper No. 11796.

Black, S.E., Devereux, P.J. \& Salvanes, K.G. 2005b. 'The more the merrier? The effect of family size and birth order on children's education', Quarterly Journal of Economics, 120(2), 669-700. 
Coase, R.H. 1960. 'The problem of social cost', Journal of Law and Economics, 3, 1-44.

Cilliers, J. 2015. A demographic history of settler South Africa. University of Stellenbosch, Stellenbosch, South Africa, Ph.D. Dissertation.

Cilliers, J. \& Fourie, J. 2012. 'New estimates of settler lifespan and other demographic trends in South Africa, 1652-1948', Economics History of Developing Countries, 27(2), 61-86.

Cilliers, J. and Fourie, J. 2014. 'Die Huwelikspatrone van Europese setlaars aan die Kaap, 16521910’, New Contree, 69, 45-70.

Dell, M. 2010. 'The persistent effects of Peru's mining mita', Econometrica, 78(6), 1863-1903.

Demsetz, H. 1967. 'Toward a theory of property rights', American Economic Review, 57(2): 347359.

De Soto, H. 2001. The mystery of capital: Why capitalism triumphs in the west and fails everywhere else. Black Swan, Berkshire.

De Villiers, J. 2012. Die Nederlandse era aan die Kaap, 1652-1806. In: Pretorius, Fransjan, (Ed), Geskiedenis van Suid-Afrika: Van voortye tot vandag. Tafelberg, Kaapstad, pp.1-50.

De Vries, J. \& Van Der Woude, A.M. 1997. The first modern economy: Success, failure, and perseverance of the Dutch economy, 1500-1815. Cambridge University Press, Cambridge.

Dooling, W. 2005. 'The making of a colonial elite: Property, family and landed stability in the Cape Colony, c. 1750-183', Journal of Southern African Studies, 31(1), 147-162.

Dooling, W. 2007. Slavery, emancipation and colonial rule in South Africa. Univ. of KwaZuluNatal Press, Scottsville.

Duly, L.C. 1968. British Land Policy at the Cape, 1795 - 1814: A Study of Administrative Procedures in the Empire. Duke Univ. Press, Durham.

Dye, A. \& La Croix, S. 2013. 'The political economy of land privatization in Argentina and Australia, 1810-1850: A puzzle', Journal of Economic History, 73(4), 901-936.

Dye, A. \& La Croix, S. 2014. Property rights in land and the extent of settlement in Dutch South Africa, 1652 - 1750 economic history seminar: LSE. [online] Available from: http://www.lse.ac.uk/economicHistory/seminars/ModernAndComparative/Papers13-

14/DyeLaCroixCape.pdf. [14 September 2015]

Feder, G. \& Feeny, D. 1991. 'Land tenure and property rights: Theory and implications for development policy', World Bank Economic Review, 5(1), 145-153.

Fenske, J.E. 2012. 'Land abundance and economic institutions: Egba land and slavery, 1830-1914', Economic History Review, 65(2), 527-555. 
Fourie, J., Jansen, A. \& Siebrits, K. 2013. 'Public finances under private company rule: The Dutch Cape Colony (1652-1795)', New Contree, 63, 51-71.

Fourie, J. \& Green, E. 2015. 'The missing people: Accounting for the productivity of indigenous populations in Cape Colonial history', Journal of African History, 56, 193-215.

Gie, S.F.N. 1963. The Cape Colony under Company Rule, 1708-1795. In: Walker, Eric A. (Ed), The Cambridge History of the British Empire, Vol. 8: South Africa, Rhodesia and the High Commission Territories. Cambridge University Press, Cambridge, pp.147-168.

Goldstein, M.P. \& Udry, C. 2008. 'The Profits of Power: Land rights and agricultural investment in Ghana', Journal of Political Economy, 106(6), 981-1022.

Goldstein, M. 2016. Securing property rights for men and women in rural Benin Gender Innovation Lab Policy Brief Issue 14 Number 103188. [online] Available at: documents.worldbank.org/curated/en/803771467991943736/pdf/103188-BRI-Securing-PropertyRights-for-Women-and-Men-in-Rural-Benin-Box394856B-PUBLIC.pdf. Accessed: 2017-02-20.

Guelke, L. 1976. 'Frontier settlement in early Dutch South Africa', Annuals of the Association of American Geography, 66(1), 25-42.

Guelke, L. 1987. The Southwestern Cape Colony 1657-1750: Freehold land grants, Occasional Paper No. 5, Geography Publication Series, Univ. of Waterloo, Waterloo.

Guelke, L. 1989. Freehold farmers and frontier settlers, 1652-1780. In: R. Elphinck and G.H. Buhr. (Eds.), The Shaping of South African Society, Maskew Miller Longman, Cape Town, pp. 66-108.

Guelke, L. \& Shell, R. 1983. 'An early colonial landed gentry: Land and wealth in the Cape Colony 1682-1731', Journal of Historical Geography, 9(3), 265-286.

Hornbeck, R. 2010. 'Barbed wire: Property rights and agricultural development', Quarterly Journal of Economics, 125(2), 767-810.

Hopkins, A.G. 1973. An economic history of West Africa. Routledge, New York.

Kantarevic, J. \& Mechoulan, S. 2006. 'Birth order, educational attainment, and earnings an investigation using the PSID', Journal of Human Resources, 41(4), 755-777.

Krzesinkski-DeWidt, A. 2002. Die Boedelinventarisse van erflaters in die distrik Stellenbosch, 1679-1806. Stellenbosch Museum, Stellenbosch.

Lamoreaux, N.R. 2011. 'The mystery of property rights: A US perspective', Journal of Economic History, 71(2), 275-306.

Mitchell, L. 2008. Belongings: Property, family, and identity in Colonial South Africa (An exploration of Frontiers, 1725 - c. 1830), Columbia Univ. Press, New York, NY.

Muldrew, C. 2011. 'From credit to savings?', Quaderni Storici, 46(2), 391-413. 
Newton-King, S. 1994. 'In search of nobility: The antecedents of Dawid van der Merwe of the Koue Bokkeveld', Collected Seminar Papers: Institute of Commonwealth Studies, 48, 26-50.

Newton-King, S. 1999. Masters and servants on the Cape eastern frontier. Cambridge Univ. Press, Cambridge.

North, D.C. 1989. 'Institutions and economic growth: An historical introduction', World Development, 17(9), 1319-1332.

Ogilvie, S., Küpter, M. \& Maegraith, J. 2012. 'Household debt in early modern Germany: Evidence from personal inventories', Journal of Economic History, 72(1), 134-167.

Place, F. \& Otsuka, K. 2000. 'Population pressure, land tenure and tree resource management in Uganda', Land Economics, 76(2), 233-251.

Schuurman, A.J. 1980. Probate inventories: Research issues, problems, and results. In: van der Woude, AdM. \& Schuurman, Anton J. (Eds). Probate inventories: A new source for the historical study of wealth, material culture and agricultural development, Wageningen pp. 19-31.

Schlager, E. \& Ostrom, E. 1992. 'Property right regimes and natural resources: A conceptual framework', Land Economics, 68(3), 249-262.

Sokoloff, K.L. \& Engerman, S.L. 2000. 'Institutions, factor endowments, and paths of development in the New World', Journal of Economic Perspectives, 14(3), 217-232.

Staiger, D. \& Stock, J.H. 1997. 'Instrumental variables regression with weak instruments', Econometrica, 65(3), 557-586.

Swanepoel, C. \& Fourie, J. 2018. 'Impending ruin or remarkable wealth? Private credit transactions in the Cape Colony', Journal of South African Studies, 44(1), 7-25.

Swanepoel, C. 2017. The private credit market of the Cape Colony, $1673-1834$ : Wealth, property rights and social networks. Univ. of Stellenbosch, Stellenbosch, Ph.D. dissertation. 